\title{
H. C. Andersen i nye teoretiske og litteratur- didaktiske klæder?
}

Steen Beck: Læs Andersen! Inspiration til undervisere og studerende. København: U Press 2019, 216 sider.

"Der er skrevet et utal af bøger om H. C. Andersen, så hvorfor skrive endnu én i rækken?” (s. 8). Sådan spørger Steen Beck retorisk og med rette i indledningen af sin bog Læs Andersen! Inspiration til undervisere og studerende. Han svarer selv med en række argumenter, der alle peger på steder, hvor forfatteren i undervisningen bliver reduceret: Beck har en "lille mistanke om" (ibid.), at H. C. Andersen ofte bliver lukket "inde i en lidt for lille og allerede defineret "eventyrkasse"” (ibid.), når han formidles til nye generationer. Beck peger også på, at den biografiske interesse står i vejen for "den egentlige anledning til mellemværendet mellem forfatteren og os" (ibid.), nemlig selve værket og dets "klogskab" (ibid.). Som et modsvar til didaktiske forsimplinger vil Beck tilbyde nye nærlæsninger særligt henvendt til lærere på ungdomsuddannelserne og i folkeskolens ældste klasser samt danskstuderende på læreruddannelser og universiteter. Bogen har således et tydeligt didaktisk sigte, og det er forfatterens håb at "afsløre nye og overraskende måder at læse H. C. Andersens eventyr på" (s. 7). Desuden er Beck motiveret af at udfordre en "fornemmelse af, at man kender Andersens eventyr" (s. 8), og han vil gerne vise, at Andersens "eventyr rummer eksistentielle dybder, man ikke sådan lige bliver færdig med" (s. 9). Bogens ærinde at altså at give undervisere inspiration til at anvende Andersens tekster i undervisningen igennem nye læsninger af kendte og mindre kendte eventyr og sætte dem i en ny didaktisk ramme, og den er skrevet til "lærere, som er optaget af nærlæsningens kunst og spændende eksistentielle perspektiver i forhold til litteraturens forunderlige måde at tale om verden på" (ibid.).

Som en konsekvens af sit fokus på nærlæsning er bogen bygget op med en indledning efterfulgt af nærlæsninger af syv af H. C. Andersens eventyr, og slutteligt fra side 173-211 kommer kapitlet "H.C. Andersen i undervisningen", hvor forfatteren træder i de litteraturdidaktiske sko. For en udenforstående læser kan det synes lidt sent for en bog, der vil tilbyde en "ny og engagerende litteraturundervisning", som bogens bagsidetekst lover. Imidlertid imødekommer Beck denne indvending allerede i indledningen, hvor han skriver, "at man ikke vil finde konkrete arbejdssedler og spørgsmål til eleverne", ligesom han "overlader det til lærerne selv at omsætte bogens ideer til konkrete måder at arrangere undervisning og arbejdsformer på" (ibid.). Beck vil tilbyde "litteraturdidaktiske principper og overordnede ideer" (ibid.), og han baserer sin viden om litteraturundervisningens muligheder og udfordringer i en nutidig skole på interviews med tre "erfarne dansklærere" (s. 173), hvis udsagn inddrages i bogens afsluttende kapitel.

Bogen er bygget op med et indledende kapitel om H. C. Andersen og hans tid. I kapitlet bliver der gjort en række relevante og oplysende nedslag i forfatterens liv, hans litteratur- og idehistoriske kontekst, dannelsestænkningen og Andersens særlige forvaltning af eventyrgenren. Herefter kommer bogens hoveddel i form af 
Becks læsninger af syv eventyr. Han har udvalgt "Nattergalen”, "Hyrdinden og Skorsteensfeieren", "De røde Skoe", "Skarnbassen", "Alt paa sin rette Plads!", "Sneedronningen" og "Skyggen". Becks læsninger er strukturerede efter to principper, som er "tæt forbundet med bogens didaktiske tilgang" (s. 10), som han beskriver som næranalyser med fokus på motiv, tema, fortælleforhold, plot osv., der kombineres med perspektiveringer til moderne psykologiske, eksistentielle, sociologiske og teologiske problemstillinger. Fx skriver Beck veloplagt et "Forsvar for skarnbassen" og viser en herlig humor og kompleksitet i eventyret, ligesom han overbevisende udfolder, hvordan "Sneedronningen" handler om "kærlighedens styrke og de kræfter, som truer de livsopretholdende relationer mellem mennesker" (s. 128). Generelt demonstrerer Beck i de ganske fyldige læsninger dyb viden og forståelse for Andersens fortællinger og foretager herlige nedslag i disse, som - forestiller jeg mig - for den intenderede målgruppe såvel vil kunne tage fat $i$ og udfolde noget velkendt som noget nyt. Nærlæsningsprincippet løst struktureret efter nykritikkens lagdeling og med belæg i fyldige citater fra eventyrene fungerer godt. Imidlertid kombineres de associativt med biografiske ekskurser, hvilket forekommer en smule paradoksalt, eftersom det detektiviske arbejde mellem biografi og værk er en af de reduktioner, han indledningsvist pegede på som en svaghed. Læs Andersen! eksemplificerer, at det kan være noget nær umuligt ikke selv at falde i den biografiske gryde fra tid til anden, fx læsningen af "Nattergalen" (s. 49-50), "Hyrdinden og Skorsteensfeieren" (s. 65-66), "De røde Skoe" (s. 89-91), "Skarnbassen" (s. 109), "Alt paa sin rette Plads" (s. 111), "Sneedronningen" (s. 152-153), "Skyggen" (s. 157-159) eller i en anden reduktionistisk faldgrube i form af den psykologiske læsning, fx i læsningen af "De røde Skoe" og "Sneedronningen".

I perspektiveringerne bliver Becks læsninger for mig at se for alvor spændende og "nye". Ansatsvis kombineres nærlæsningerne med fx det antropocæne i læsningen af "Nattergalen," hvor Løgstrup anvendes som reference, uden at det ender med en simplificerende økokritisk læsning. Eller når Løgstrups begreb om de suveræne livsytringer bruges til at karakterisere Gerda i "Sneedronningen" som værende i besiddelse af en "intuitiv bevidsthed", der styrer hendes etiske handlekraft. På lignende vis inddrages blandt andre Kierkegaard, Sartre, Honneth, Nietzsche, Girard og Goffman kontekstualiserende i læsningerne af de andre eventyr. Det bliver åbenlyst nok en smule eklektisk, når så store teoretikere anvendes ansatsvis, men omvendt er det også her, læsningerne for alvor bidrager med noget nyt og revitaliserende. Ad denne vej er der potentiale til yderligere nylæsninger af Andersens eventyr, fx ud fra nyere litteraturteoretiske grene, der inkorporerer en tydelig verdensvendthed som fx den såkaldte sociale vending, materielle drejning og de i det hele taget mere emotionelle eller etiske tilgange til at læse og forstå litteratur. Hér er der også litteraturdidaktiske potentialer, som kunne bidrage væsentligt til at gentænke Andersens eventyr i undervisningen, men det er ikke den vej, Læs Andersen! går.

Det sidste kapitel "H. C. Andersen i undervisningen" handler om, "hvordan man kan undervise i Andersens eventyr i den senmoderne skole" (s. 13). Forestillingen om den senmoderne skole henter Beck hos Thomas Ziehe, der i en bog fra 2004 udviklede sine tanker om den såkaldte "kulturelle frisættelse" og "god anderledeshed". Ziehes karakteristik af ungdomskulturen er der for så vidt ikke noget i vejen med ud over, at teknologiske fremskridt som internettets udbredelse, smartphones 
og andre enheder har afgørende indflydelse på SoMe-generationen, og i det lys kan det virke som en smule bedaget at fremhæve unges præferencer for "film og tegneserier" (s. 174). Nuvel, Facebook bliver også nævnt, men jeg savner mere generelle overvejelser over, hvordan man fagdidaktisk kan både arkivere og aktualisere (med to begreber i kanondidaktikken fra Handesten og Weinreich) ældre tekster for unge, der (som voksne) lever i en kultur med samtidighed af udtryksformer som skrift, billede og lyd og daglig omgang med en mangfoldighed af forskellige medier. Desuden tager Beck fat i Wolfgang Klafkis begreb om kategorial dannelse. Al respekt for Klafkis klassiske tænkning, som jeg selv skatter højt, men han bidrager ikke for alvor med noget nyt og aktuelt i litteraturundervisningen, og det samme gør sig gældende i resten af kapitlet, hvor tanker om nærlæsning med fokus på bl.a. den litteraturanalytiske (og nykritiske) værktøjskasse med fx handling, plot, aktantmodel (lånt fra strukturalisme), fortælleforhold og motivanalyse bliver fremhævet som mulige veje i undervisningen. På lignende vis er der et afsnit med udgangspunkt i receptionsæstetik, hvor mulighederne for at meddigte og fylde "tomme pladser" ud beskrives, og et afsnit om historisk kontekstualisering fremhæves. Disse tre måder at arbejde litteraturdidaktisk er alle velkendte og veletablerede i litteraturundervisningen på godt og ondt og kigger mere i bakspejlet end ud af forruden i forhold til at udvikle litteraturdidaktikken og formidle H. C. Andersen til nye generationer. Her undrer jeg mig over, at Beck ikke i langt højere grad tager de litteraturdidaktiske konsekvenser af sine interessante læsninger og fx tænker de eksistentielle, etiske og sociologiske tænkere direkte ind i litteraturundervisningen. En oplagt måde at gøre det på, er ved at sætte Andersens tekster i dialog med andre tekster af såvel kanoniserede som helt aktuelle forfattere, billedkunstnere, musikere osv. Ad den vej kan der for alvor komme nye perspektiver på ældre tekster, og det bliver mere åbenlyst, hvordan de både udsiger noget om den tid, de er skabt i, og om den tid, de bliver læst i. Desuden er der et åbenlyst potentiale i at arbejde med remedieringer af Andersens eventyr med moderne unge. Her nævner Beck selv og som de eneste eksempler Disneys Den lille havfrue eller Frozen. Hertil har jeg lyst til at nævne den danskproducerede filmversion af De vilde svaner og Lars Gabels illustrerede versioner af Den lille havfrue, Snedronningen, Fyrtøjet og Nattergalen, som er vilde og føjer nye dimensioner til eventyrene, og som vil passe bedre til målgruppen, der er folkeskolens ældste elever og ungdomsuddannelserne. At arbejde med remedieringer både receptivt og produktivt er der mange litteraturdidaktiske potentialer i, som kan give grobund for, at eleverne sensitivt dykker ned i eventyrene og nærlæser fx symbolik og tematik og samtidig selv er producerende og udtrykker sig ved hjælp af digitale redskaber og medier, som de både kender og har brug for at kvalificere deres anvendelse af.

Så til det indledende spørgsmål om, hvorvidt det er muligt at legitimere endnu en bog om H. C. Andersen, bliver svaret et både og: Vil bogen revitalisere undervisningen i forfatteren, så bliver svaret nej, vil bogen tilbyde perspektiverende læsninger, så ja.

Anmeldt af Ayoe Quist Henkel 